\title{
Tomato and sweet pepper response to furrow, microsprinkler and drip irrigation'
}

\author{
Megh R. Goyal and Carmela Chao de Báez ${ }^{2}$
}

\begin{abstract}
Fortuna Agricultural experiment substation, Juana Díaz, in the semiarid south coast and Isabela agricultural experiment substation in the humid north coast of Puerto Rico were selected as representative locations in each region. Field work was conducted during the winter at Fortuna: drip, microsprinkler and furrow irrigation increased commercial yield of (mature green + red) staked tomatoes by $112 \%, 82 \%, 37 \%$ compared with control plots during the winter of 1987. Values of growth parameters were lowest in the nonirrigated plots at $P=0.05$. Based upon tensiometer readings, total water application ( $\mathrm{mm}$ per season for 120 days) was 1050 in furrow, 611 in microsprinkler and 386 in drip irrigation, respectively during the winter at Fortuna. Seasonal net irrigation requirement (NIR, $\mathrm{mm}$ ) was estimated with the modified Blaney-Criddle USDA-SCS method and was 336 in normal years and 409 in dry years at Fortuna; 253 in normal years and 311 in dry years at Isabela in the winter. Total NIR was 399 in normal years and 492 in dry years at Fortuna; 262 in normal years and 357 in dry years at Isabela in summer, respectively. CU at Fortuna was 7 to $7.6 \%$ higher than CU at Isabela. NIR at Fortuna was 25 to $35 \%$ higher than at Isabela. At Fortuna sweet pepper yield and values of growth parameters were lowest in the nonirrigated plots at $P=0.05$ during the winter and summer. Drip, micropsprinkler and furrow irrigation increased commercial yield of sweet pepper by $168 \%, 115.5 \%, 52 \%$ compared to that of control plots during the winter; and $186 \%, 119.6 \%, 85 \%$ compared to control plots during the summer, respectively. Silver coated plastic mulch increased the yield during winter and summer. Growth parameters versus days after transplanting relationships were of sigmoidal type. Based upon tensiomenters at $30 \mathrm{~cm}$ depth and a tension reading of $15-45 \mathrm{cbar}$, total water application ( $\mathrm{mm}$ per season for 120 days) was 1260 in furrow, 524 in mierosprinkler and 406 in drip irrigation during the winter; and 951 in furrow, 542 in mierosprinkler and 419 in drip irrigation during the summer, respectively. No field work was conducted at Isabela. Seasonal net irrigation requirement (NIR, mm) of sweet peppers was 341 for winter and 352 for summer in normal years.
\end{abstract}

\section{RESUMEN}

Respuesta de tomate y pimiento a tres métodos de riego: infiltración, microaspersores y goteo

Las subestaciones experimentales de fortuna e Isabela están lacalizadas en la costa sur semiárida y en la costa norte húmeda de Puerto Rico, respectivamente. Se establecieron experimentos de campo solamente

'Manuscript submitted to Editorial Board 16 February 1989. This research was conducted under H-326-A (S-143), "Trickle Imigation in Humid Regions-Puerto Rico". Authors thank Eladio A. González and Luis E. Rivera for their assistance.

${ }^{2}$ Agricultural Engineer and Associate Statistician, Agricultural Experiment Station University of Puerto Rico, Río Piedras, P.R. 
en Fortuna. Los sistemas de riego por goteo, microaspersores e infiltración aumentan el rendimiento comercial de tomates (hecho + maduro) en invierno en un $112 \%, 82 \%$ y $37 \%$, al compararse con el testigo, repectivamente. Basándonos en la lectura de tensiómetros, la aplicación total de agua (mm. por temporada para 120 dias) fué 1050 en riego por infiltración, 611 por microaspersores y 386 por riego por goteo en invierno, en Fortuna. Los valores de los parámetros de crecimiento fueron significativamente más bajos $(P=0.05)$ en los tratamientos no regados. Los requisitos de riego neto para fomate (RRN, $\mathrm{mm}$.) con el método BlaneyCriddle fueron 336 para años normales, 409 para años secos en Fortuna; 253 para años normales y 311 para años secos en Isabela en invierno. RRN fueron 399 en años normales, 492 en años secos en Fortuna; 262 en años normales y 357 en años secos en Isabela en el verano, respertivamente. El $\mathrm{CU}$ en Fortuna fué de 7 a $7.6 \%$ más alto que en Isabela y RRM en Fortuna fué de 25 a $35 \%$ más alto que en Isabela.

En Fortuna, la producción de pimientos y los valores de los parámetros de crecimiento fueron significativamente más bajos $(P=0.05)$ en las parcelas no regadas. El riego por gotea, por microaspersores y por infiltración aumentó la producción comercial en invierno en un $168 \%, 115.5 \%$ y $52 \%$, respectivamente, al compararlos con el testigo; y $186 \%, 119.6 \%$ y $85 \%$ en el verano. La cubierta plástica plateada aumentó la producción en invierno y verano. la relación entre los parámetros de crecimiento contra los días después del trasplante fue de tipo sigmoide. Según la lectura de los tensiómetros a $30 \mathrm{~cm}$. de profundidad y una tensión de $15-45$ cbares, la aplicración total de agua ( $\mathrm{mm}$. por temporada para 120 dias) fue 1260 en riego por infiltración, 524 en microaspersores y 406 en riego por goteo en el invierno; mientras que en el verano fue 951 en infiliración, 542 en microaspersores y 419 riego por goteo, respectivamente. Los requisitos de riego neto para pimientos (RRN, mm.) fueron 341 en invierno y 352 en verano. No se realizó ningún trabajo en Isabela.

\section{INTRODUCTION}

Of the 11.6 billion hectares of land in a 103-country survey, only $3.6 \%$ is cultivated (3), about $20 \%$ of which is under irrigation. Some countries report $100 \%$ of their cultivated land under irrigation, and others have practically no irrigation. There is a projected addition of some 22 million hectares of new irrigation and 45 million hectares of improvement of existing irrigation in the developing regions of the world. The proportion of the water supply in the world used for irrigation was expected to increase from $70 \%$ in 1967 to a projected $51 \%$ in year 2000 . Although the annual rate of growth of irrigation will be about $2.1 \%$, the growth of urban, domestic and industrial demand will grow at a rate of 4 to 5\%. This indicates that a formidable effort will be needed in the next 2 decades to develop water resources and to improve irrigation systems if we have to feed the world at a minimum acceptable standard of nutrition (2, $3,6)$. We need to evaluate and compare existing irrigation systems.

The objectives of this study were: 1) to estimate irrigation requirement of tomatoes in the semiarid and humid regions of Puerto Rico with the modified Blaney-Criddle (USDA-SCS) method; 2) to estimate irrigation requirement of sweet pepper in the semiarid region of Puerto Rico with the modified Blaney-Criddle method; 3) to evaluate tomato (var. 
Duke) response to furrow, microsprinkler, drip irrigation and no irrigation during the winter at Fortuna Substation; and 4) to evaluate sweet pepper (var. Cubanelle) response to furrow, microsprinkler, drip irrigation, no irrigation and plastic mulching during the winter and summer also at Fortuna. Fortuna agricultural experiment substation, in the semiarid south coast and Isabela agricultural experiment substation in the humid north coast of Puerto Rico were selected.

\section{MATERIALS AND METHODS}

Irrigation requirement estimations

Factors that affect net irrigation requirements were identified by Goyal (4). Temperature and rainfall data $(1,9)$ of tables 1 and 2, USDASCS computer program (5), USDA-SCS technical release No. 21 (10) and procedure described by Goyal (4) were used to estimate NIR and gross irrigation requirements (GIR). For normal years, NIR and GIR for sweet peppers were computed from 18 December 1986 to 14 April 1987 and 21. April to 19 August 1987 at Fortuna. NIR and GIR for tomato were also computed from 1 December 1987 to 28 March 1988 and 1 April to 28 July 1988 at Fortuna and Isabela substations for normal and dry years.

\section{Field experiment}

The plants were spaced $30 \mathrm{~cm}$ down the row. Dual chamber drip

TABLE 1.-Climatic variables to estimate net irrigation requirement of peppers at the Fortuna Substation

\begin{tabular}{|c|c|c|c|c|c|}
\hline \multirow[b]{2}{*}{$\begin{array}{l}\text { Month } \\
1986-87\end{array}$} & \multicolumn{5}{|c|}{ Climatic Variables' } \\
\hline & $\mathrm{K}_{\mathrm{t}}$ & $\mathrm{K}_{\mathrm{c}}$ & $\begin{array}{c}\text { Mean } \\
\text { temp., }{ }^{\circ} \mathrm{C}\end{array}$ & $\begin{array}{l}\text { Mean } \\
\text { rainfall, } \mathrm{cm}\end{array}$ & $\% \mathrm{DLH}$ \\
\hline \multicolumn{6}{|c|}{ Winter Sweet Peppers } \\
\hline Dec 18-31 & 1.03 & 0.51 & 25.3 & 1.54 & 7.91 \\
\hline Jan & 1.00 & 0.60 & 24.5 & 2.18 & 8.00 \\
\hline Feb & 1.0 & 0.96 & 24.3 & 2.72 & 7.18 \\
\hline May & 1.01 & 1.01 & 24.8 & 1.55 & 8.25 \\
\hline April 1-14 & 1.04 & 0.95 & 25.7 & 2.70 & 8.28 \\
\hline Total & - & - & - & 10.69 & - \\
\hline \multicolumn{6}{|c|}{ Summer Peppers } \\
\hline April 21-30 & 1.04 & $0.5 \mathrm{I}$ & 25.7 & 1.93 & 8.28 \\
\hline May & 1.06 & 0.56 & 26.5 & 11.40 & 9.16 \\
\hline June & 1.09 & 0.91 & 27.2 & 8.92 & 9.18 \\
\hline July & 1.10 & 1.02 & 27.5 & 6.96 & 8.92 \\
\hline Aug $1-19$ & 1.10 & 0.95 & 27.6 & 7.30 & 8.72 \\
\hline Total & - & - & - & 36.51 & - \\
\hline
\end{tabular}


TABLE 2.-Climatic variables to estimate net irrigation requirements of tomatoes in. Puerto Rico $(9,10)$

\begin{tabular}{|c|c|c|c|c|c|}
\hline \multirow[b]{2}{*}{$\begin{array}{l}\text { Month } \\
1987-88\end{array}$} & \multicolumn{5}{|c|}{ Climatic Variables' } \\
\hline & $\mathrm{K}_{\mathrm{t}}$ & $\mathrm{K}_{\mathrm{c}}$ & $\begin{array}{c}\text { Mean } \\
\text { temp., }{ }^{\circ} \mathrm{F}\end{array}$ & $\begin{array}{c}\text { Mean } \\
\text { rainfall, in. }\end{array}$ & $\% \mathrm{DLH}$ \\
\hline & \multicolumn{5}{|c|}{ Fortuna Substation } \\
\hline Dec 1-31 & 1.03 & 0.60 & 77.6 & 1.34 & 7.91 \\
\hline Jan & 1.00 & 1.04 & 76.1 & 0.86 & 8.00 \\
\hline Feb & 1.00 & 1.05 & 75.8 & 1.07 & 7.18 \\
\hline \multirow[t]{2}{*}{ Mar 1-28 } & 1.01 & 0.78 & 76.6 & 0.61 & 8.25 \\
\hline & \multicolumn{5}{|c|}{ Seasonal total $=3.88$} \\
\hline April & 1.04 & 0.60 & 78.2 & 2.28 & 8.28 \\
\hline May & 1.06 & 1.04 & 79.7 & 4.49 & 9.16 \\
\hline June & 1.09 & 1.05 & 80.9 & 3.51 & 9.18 \\
\hline \multirow[t]{3}{*}{ July 1-28 } & 1.10 & 0.78 & 81.5 & 2.74 & 8.92 \\
\hline & \multicolumn{5}{|c|}{ Seasonal total $=13.02$} \\
\hline & \multicolumn{5}{|c|}{ Isabela Substation } \\
\hline Dec 1-31 & 0.99 & 0.60 & 75.1 & 4.32 & 7.88 \\
\hline $\operatorname{Jan}$ & 0.96 & 1.04 & 73.5 & 3.80 & 7.97 \\
\hline Feb & 0.96 & 1.05 & 73.4 & 3.34 & 7.18 \\
\hline \multirow[t]{2}{*}{ Mar 1-28 } & 0.97 & 0.78 & 74.5 & 3.25 & 8.26 \\
\hline & \multicolumn{5}{|c|}{ Seasonal total $=14.71$} \\
\hline April & 0.99 & 0.60 & 75.5 & 4.84 & 8.30 \\
\hline May & 1.02 & 1.04 & 77.1 & 8.44 & 9.17 \\
\hline June & 1.04 & 1.05 & 78.3 & 7.54 & 9.18 \\
\hline \multirow[t]{2}{*}{ July $1-28$} & 1.05 & 0.78 & 79.1 & 5.00 & 8.95 \\
\hline & \multicolumn{5}{|c|}{ Seasonal total $=25.84$} \\
\hline
\end{tabular}

laterals with orifice spacing of $60 \mathrm{~cm}$ in 1.8 beds were used to supply moisture in the drip irrigated plots (T1). Laterals of 16-mm poly tubing with microsprinklers (fig. 1) at predetermined spacing were used in the sprinkler irrigated plots (T2) with the plants at the sides of the bed. A field manifold delivered water from the submain to each furrow in the conventional irrigation system (T3). In the nonirrigated plots (T4), drip irrigation system was used up to 45 days after transplanting. Outer beds in each plot were left as a border to avoid interaction among treatments. Soil moisture status $(2,8)$ in each plot was measured with tensiometers at $15-\mathrm{cm}$ soil depth. Irrigation scheduling was based upon soil moisture tension of 15-45 cbars. One plant/plot was removed each successive week to determine weekly fresh and dry weight of plant and fruit. Fruits were manually harvested in 5 pickings. Fertilizer and pesticides were applied according to recommendations by the Agricultural Experiment Station of the University of Puerto Rico (7).

Experiment 1. At Fortuna substation, four-week old pepper transplants (var. Cabanelle) were planted on both sides of the biwall drip tubing in 


\section{TREATMENT - TI = DRIP IRRIGAIICN}

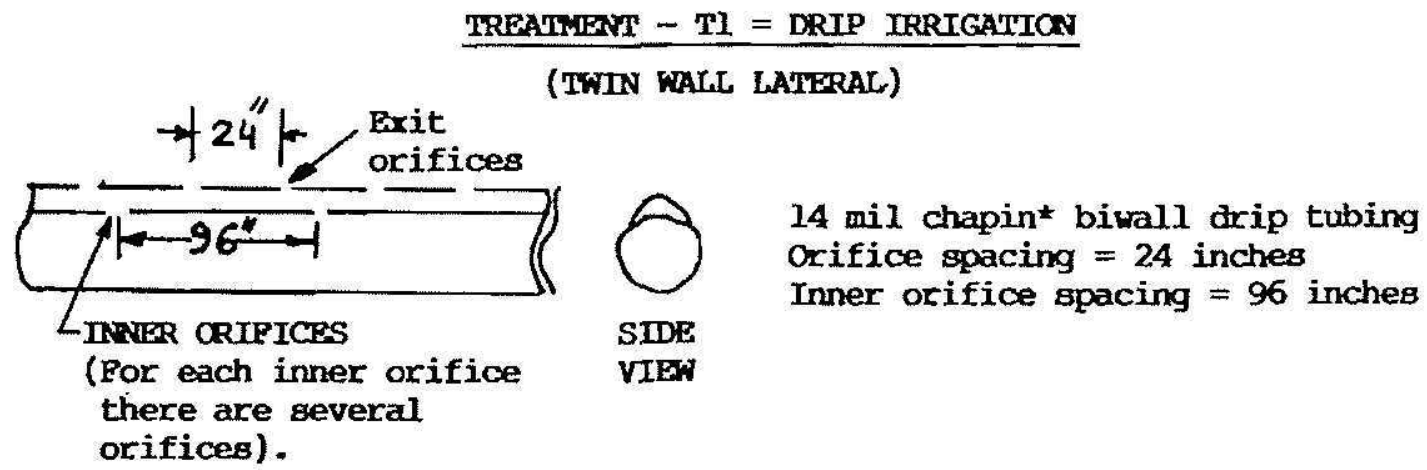

TREATMIENT - T2 = MTNI SPRINITLER ON WEDTEE
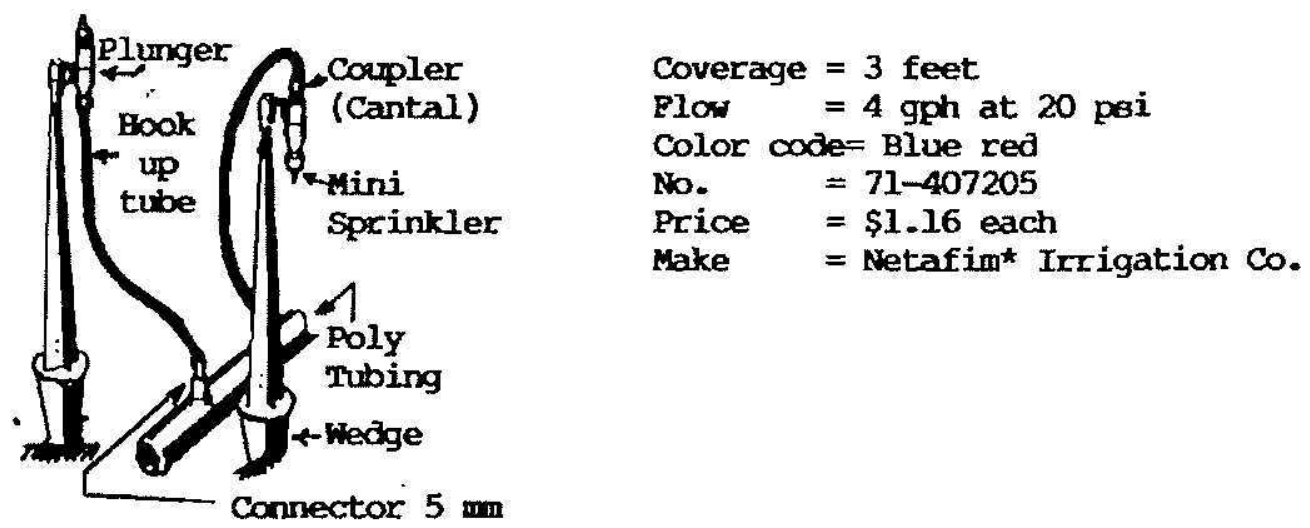

TRRATGEAT - T3 = FURROW IRRIGATTON

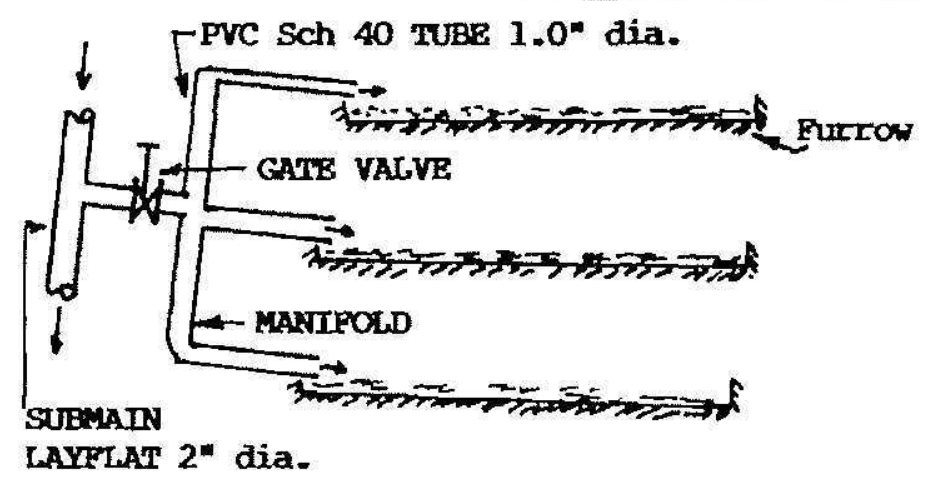

Figure 1.-Three irrigation systems to evaluate tomato and sweet pepper. *Trade names are used only to provide specific information. Mention of a trade name does not imply preference over other materials.

a zigzag pattern and at a distance of $15 \mathrm{~cm}$ from the drip tubing. The irrigation treatments were replicated 4 times in a split-plot complete randomized block design. Split-plots were used to evaluate effect of silver coated plastic mulch on crop response (P and NP). During the winter of 1986-87, peppers were transplanted 18 December 1986, and the experiment was terminated 14 April 1987. During the summer of 1986-87, peppers were transplanted 21 April 1987 and the experiment was terminated 
19 August 1987. No experimental work was conducted at Isabela substation.

Experiment 2. At Fortuna substation, six-week old tomato transplants (var. Duke) were planted 1 December 1987 on windward sides of the biwall drip tubing and at a distance of $15 \mathrm{~cm}$ from the drip line. The irrigation treatments were replicated four times in a complete randomized block design. Tomatoes were staked. The experiment was terminated 28 March 1988. No experimental work was conducted at Isabela in winter; neither at Fortuna nor at Isabela in summer.

\section{RESULTS AND DISCUSSION}

\section{Swweet Pepper}

Table 3 shows net irrigation requirement (NIR) and gross irrigation requirement (GIR) of sweet pepper during the winter and summer of 1986-87 at Fortuna agricultural experiment substation. Seasonal CU was $400 \mathrm{~mm}$ for winter and $516 \mathrm{~mm}$ for summer peppers. Mean effective rainfall $(\mathrm{ER}, \mathrm{mm})$ was 59 in winter and 164 in summer. Total NIR (mm) was 341 for winter and 352 for summer peppers. Monthly NIR (mm) was

TABLE 3.-Estimation of gross irrigation requirements of sweet peppers in winter and summer at Fortuna Agricultural Experiment Substation, Juana Diaz, P.R.

\begin{tabular}{|c|c|c|c|c|c|c|}
\hline \multirow[b]{2}{*}{$\begin{array}{l}\text { Month } \\
1986-87\end{array}$} & \multicolumn{3}{|c|}{ Net Irrigation requirement $(\mathrm{NIR}, \mathrm{cm})^{1}$} & \multicolumn{3}{|c|}{ Gross requirements $(\mathrm{cm})^{2}$} \\
\hline & CU & $\mathrm{ER}$ & NIR & Furrow & $\begin{array}{c}\text { Mini } \\
\text { Sprinkler }\end{array}$ & Drip \\
\hline \multicolumn{7}{|l|}{ Winter Peppers } \\
\hline Dec 18-31 & 2.74 & 1.40 & 1.34 & 3.25 & 2.23 & 1.68 \\
\hline Jan & 7.42 & 0.81 & 6.60 & 16.50 & 11.00 & 8.25 \\
\hline Feb & 10.64 & 1.09 & 9.55 & 23.88 & 15.92 & 11.94 \\
\hline May & 13.18 & 0.64 & 12.54 & 31.35 & 20.90 & 15.66 \\
\hline April 1-14 & 6.04 & 1.98 & 4.06 & 10.15 & 6.77 & 5.08 \\
\hline Total & 40.00 & 5.92 & 34.08 & 85.20 & 56.80 & 44.60 \\
\hline Efficiency (measured) ${ }^{3}$ & & & & $37 \%$ & $65 \%$ & $84 \%$ \\
\hline \multicolumn{7}{|l|}{ Summer Peppers } \\
\hline April 21-30 & 2.08 & 2.08 & 0.00 & 0.00 & 0.00 & 0.00 \\
\hline May & 8.81 & 3.81 & 5.00 & 12.50 & 8.33 & 6.25 \\
\hline June & 14.94 & 3.53 & 11.41 & 28.53 & 19.02 & 14.27 \\
\hline July & 16.48 & 2.95 & 13.53 & 33.83 & 22.55 & 16.92 \\
\hline Aug 1-19 & 9.25 & 4.01 & 5.24 & 13.10 & 8.73 & 6.55 \\
\hline Total & 51.56 & 16.36 & 35.20 & 88.00 & 58.67 & 44.00 \\
\hline
\end{tabular}

${ }^{1} \mathrm{CU}=$ Consumptive use $(\mathrm{cm})$ with modified Blaney-Criddle USDA-SCS; ER = effective rainfall $(\mathrm{cm}) ; \mathrm{NIR}=$ net irrigation requirement.

${ }^{2} \mathrm{GIR}=\mathrm{NIR} / \mathrm{IE}$, where $\mathrm{IE}=$ irrigation efficiency in fractions ( $40 \%$ for gravity; $60 \%$ for minisprinkler, and $80 \%$ for drip irrigation).

${ }^{3}$ Efficiency measured $=($ NIR/total water applied $) \times 100$. 
13.4 in December, 66 in January, 96 in Febrary, 125 in March and 41 in April. Monthly NIR (mm) was 0.0 in April, 50 in May, 114 in June, 135 in July, 52 in August.

Seasonal GIR (mm) was 446 for drip, 568 for microsprinkler, 852 for furrow irrigation during the winter. Total GIR was 440 for drip, 587 for microspinkler and 880 for furrow irrigation during the summer. Average daily CU was $2.9 \mathrm{~mm} /$ day ( $=0.11$ in per day) in winter compared to 3.0 $\mathrm{mrn} /$ day (0.12 in per day) in summer. Based upon tensiometer readings, total water application ( $\mathrm{nm} / \mathrm{season}$ for 120 days) was 921 for furrow, 524 for microsprinkler and 406 for drip irrigation during the winter. Total water application 951 for furrow, 541 for microsprinkler and 419 for drip irrigation during the summer, respectively.

Table 4 indicates commercial pepper yield in the drip irrigated ( $\mathrm{Ti}$ ), sprinkler irrigated (T2), furrow irrigated (T3) and control plots (T4) with plastic mulching $(\mathrm{P})$ and no mulching (NP), respectively during the winter and summer. In both seasons, plastic mulching (P) significantly increased yield at $\mathrm{P}=0.05$. In $\mathrm{P}$ and $\mathrm{NP}$ plots, T4 plots yield was significantly lowest $(\mathrm{P}=0.05)$ compared to $\mathrm{T} 1, \mathrm{~T} 2$ and $\mathrm{T} 3$ plots, respectively. Drip irrigation significantly increased yield at $\mathrm{P}=0.05$ compared to that with microsprinkler and furrow irrigation. Microsprinkler irrigation gave sigificantly better crop performance than furrow irrigation. Drip, microsprinkler, and furrow irrigation increased commercial pepper yield by $168 \%, 115.5 \%, 52 \%$ compared with that of nonirrigated plots in winter;

TABLE 4,-Pepper response to irrigation methods and plastic mulch at Fortuna Agricultural Experiment Substation, Juana Diaz, P.R.

\begin{tabular}{crrr}
\hline & \multicolumn{2}{c}{ Average cornmercial yield, $\mathrm{kg} / \mathrm{ha}$} \\
\cline { 2 - 4 } Treatment' & Plastic mulch $(\mathrm{P})$ & No plastic (NP) & Mean \\
\hline & & Winter peppers, $1986-87$ & \\
T1 & 37334.4 & 25942.1 & $31638.2 \mathrm{a}$ \\
T2 & 28890.4 & 21072.9 & $24981.6 \mathrm{~b}$ \\
T3 & 24048.1 & 11961.9 & $18005.0 \mathrm{c}$ \\
T4 & 16855.5 & 6765.0 & $11810.2 \mathrm{~d}$ \\
Mean & 26782.1 & 16435.5 & 21608.8 \\
& & & \\
T1 & 31067.2 & 21450.1 & $26258.6 \mathrm{a}$ \\
T2 & 23533.9 & 16700.9 & $20117.4 \mathrm{~b}$ \\
T3 & 20999.9 & 12919.2 & $16959.5 \mathrm{c}$ \\
T4 & 11274.2 & 7046.4 & $9160.3 \mathrm{~d}$ \\
Mean & 21718.8 & 14529.2 & 18124.0 \\
\hline
\end{tabular}

${ }^{\mathrm{T}} \mathrm{T} 1=$ Drip irrigation (Biwall drip line); $\mathrm{T} 2=$ micro-sprinkler irrigation; $\mathrm{T} 3=$ Furrow irrigation (conventional); $\mathrm{T} 4=$ control (drip irrigated only for 40 days after transplanting); $\mathrm{P}=$ silver coated plastic mulch and NP $=$ Without plastic mulch.

${ }^{2}$ Means followed by the same letter do not differ significantly at the $1 \%$ probability level. 


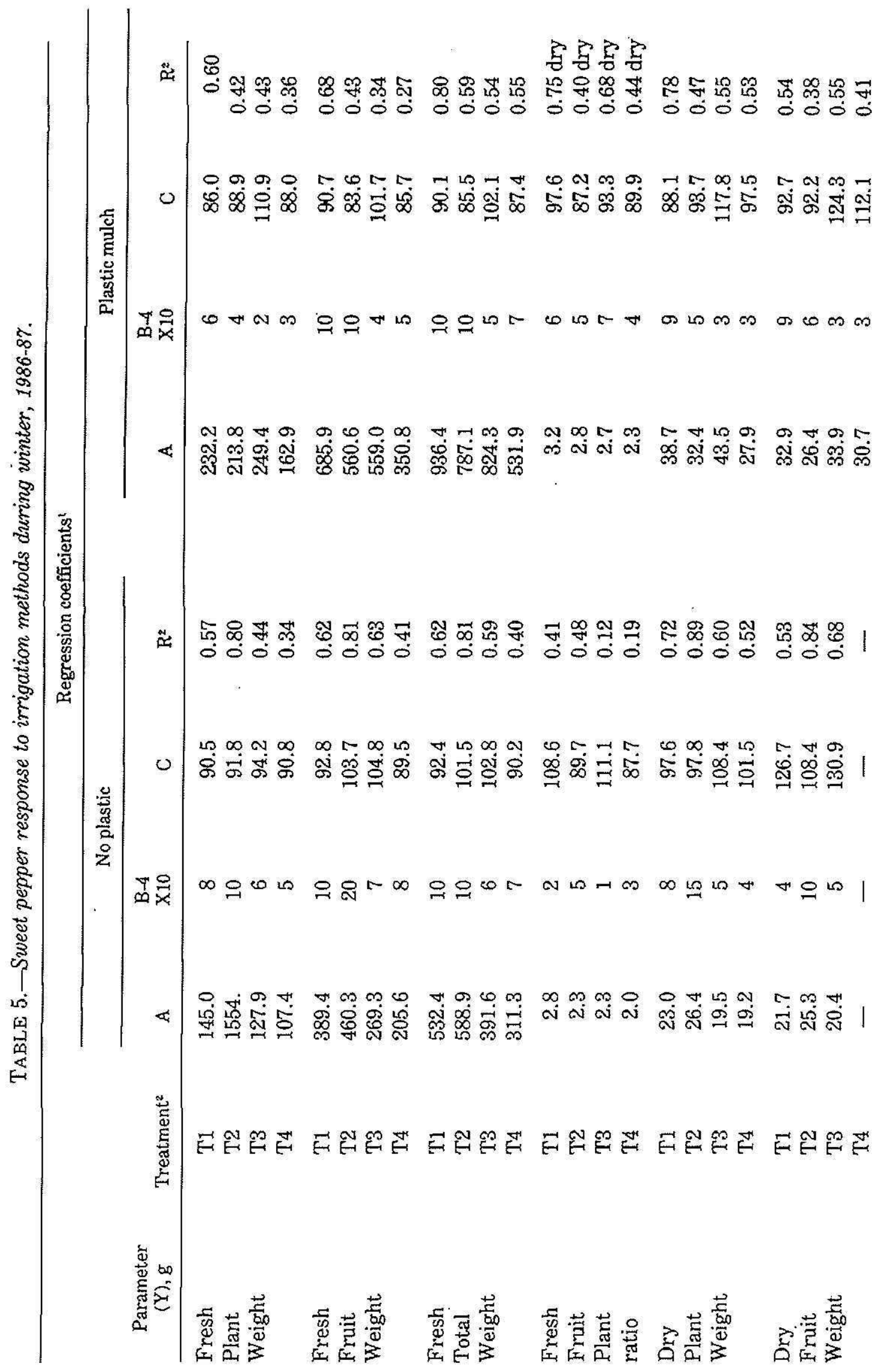




\begin{tabular}{|c|c|c|c|c|c|c|c|c|c|}
\hline Dry & $\mathrm{T} 1$ & 41.1 & 6 & 103.3 & 0.65 & 71.6 & 9 & 90.0 & 0.78 \\
\hline Total & $\mathrm{T} 2$ & 50.2 & 10 & 102.9 & 0.88 & 58.9 & 5 & 93.2 & 0.52 \\
\hline \multirow[t]{2}{*}{ Weight } & T3 & 38.2 & 4 & 121.1 & 0.68 & 76.7 & 3 & 119.6 & 0.61 \\
\hline & $\mathrm{T} 4$ & 35.6 & 3 & 114.4 & 0.45 & 57.8 & 3 & 103.2 & 0.51 \\
\hline
\end{tabular}

${ }^{1}$ All regression coefficients were significant at $\left.\left.P=0.05 . Y=A /\right) 1+B(C-X)^{2}\right)$, where $Y=$ growth parameter $(g)$, $X=$ days after transplanting and $\mathrm{A}, \mathrm{B}, \mathrm{C}=$ regression coefficients.

${ }^{2} \mathrm{~T} 1=$ drip irrigation, $\mathrm{T} 2=$ microsprinkler, $\mathrm{T} 3=$ furrow irrigation and $\mathrm{T} 4=$ control. 
and by $186 \%, 119.6 \%, 85 \%$ compared with nonirrigated plots in summer, respectively. During the winter, commercial yield (tons/ha) was $37.3 \mathrm{in}$ $\mathrm{T} 1,28.9$ in T2, 24.0 in T3, 16.9 in T4 plots with plastic mulching. With no mulching, yield was 25.9 in $\mathrm{T} 1,28.9$ in $\mathrm{T} 2,11.9$ in $\mathrm{T} 3$ and 6.8 in $\mathrm{T} 4$ plots. During the summer, yield (tons/ha) was 31.1 in T1, 23.5 in T2, 21.0 in T3, 11.3 in T4 plots with silver coated plastic mulch; 21.5 in T1, 16.7 in T2, 12.9 in T3 and 7.0 in T4 in plots with no mulching. Water use efficiency of peppers (commercial yield/gross water requirement, t/ha-cm) was:

\begin{tabular}{llccc} 
& & Drip & Microsprinkler & Furrow \\
a) Winter & $\mathrm{P}$ & 0.92 & 0.55 & 0.26 \\
& $\mathrm{NP}$ & 0.64 & 0.40 & 0.13 \\
b) Summer & $\mathrm{P}$ & 0.74 & 0.44 & 0.22 \\
& $\mathrm{NP}$ & 0.51 & 0.31 & 0.14 \\
\multicolumn{2}{l}{ Overall average } & 0.70 & 0.43 & 0.19
\end{tabular}

Mean ranges are within the ranges reported by other investigators ( 2 , $3,6)$.

Relationships among fresh plant-, fresh fruit-, fresh total-, dry plant-, dry fruit-, dry total weight and fruit/plant ratio versus days after transplanting (table 5) were of sigmoidal type. These relationships were described by the following equation:

$$
\begin{aligned}
\mathrm{Y} & =\mathrm{A} /(\mathrm{I}+\mathrm{B} \times(\mathrm{C}-\mathrm{X}) \times(\mathrm{C}-\mathrm{X})) \\
\text { where } \mathrm{Y} & =\text { growth parameter, } \mathrm{g} \\
\mathrm{X} & =\text { days after transplanting } \\
\mathrm{A}, \mathrm{B}, \mathrm{C}_{1} & =\text { regression coefficients } \\
\mathrm{R}^{2} & =\text { coefficient of determination }
\end{aligned}
$$

All regression coefficients were significant at $P=0.05$. $R^{2}$ varied from 0.123 to 0.89 .

\section{Tomato}

Table 6 shows net irrigation requirement (NIR) and gross irrigation requirement (GIR, $\mathrm{cm}$ ) of tomato during the winter of 1987-88 at Fortuna and Isabela agricultural experiment substations. During normal years, seasonal CU was $413 \mathrm{~mm}$ at Fortuna and 383 at Isabela. Mean effective rainfall (ER) was $77 \mathrm{~mm}$ at Fortuna and $130 \mathrm{~mm}$ at Isabela. NIR was 336 $\mathrm{mm}$ at Fortuna and $253 \mathrm{~mm}$ at Isabela. Monthly NIR (mm) was 64 for December, 107 for January, 88 for February, 58 for March at Isabela. Seasonal GIR (mm) was 842 for furrow, 560 for minisprinkler and 421 for drip irrigation at Fortuna; and 632 for furrow, 421 for minisprinkler and 316 for drip irrigation at Isabela. Average daily NIR ( $\mathrm{mm} /$ day) was 2.8 at Fortuna and 2.1 at Isabela. With irrigation applications based on tensiometer readings, total irrigation application ( $\mathrm{mm} / \mathrm{season}$ ) was 386 for drip, 611 for minisprinkler and 1050 for furrow irrigation at Fortuna. No 
TABLE 6.-Estimation of gross irrigation requirements of tomatoes at Fortuna and Isabela

\begin{tabular}{|c|c|c|c|c|c|c|}
\hline \multicolumn{7}{|c|}{ Winter tomatoes } \\
\hline \multirow[b]{2}{*}{$\begin{array}{l}\text { MONTH } \\
1987-88\end{array}$} & \multicolumn{3}{|c|}{ Net Irrigation requirement $(\mathrm{N} I \mathrm{R}, \mathrm{cm})$} & \multicolumn{3}{|c|}{ Gross Irrigation requirements(GIR, $(\mathrm{cm})$} \\
\hline & $\mathrm{CU}$ & ER & NIR & Furrow & $\begin{array}{c}\text { Mini } \\
\text { Sprinkler }\end{array}$ & Drip \\
\hline \multicolumn{7}{|c|}{ Fortuna substation (normal years) } \\
\hline Dec 1-31 & 7.67 & 1.27 & 6.40 & 16.0 & 10.7 & 8.0 \\
\hline Jan & 12.88 & 2.18 & 10.70 & 26.8 & 17.8 & 13.4 \\
\hline Feb & 11.56 & 2.72 & 8.84 & 22.2 & 14.7 & 11.1 \\
\hline Mar 1-28 & 9.22 & 1.55 & 7.67 & 19.2 & 12.8 & 9.6 \\
\hline Total & 41.33 & 7.72 & 33.61 & 84.2 & 56.0 & 42.1 \\
\hline \multicolumn{3}{|c|}{ Gross irrigation applied, $\mathrm{cm}=$} & & 105.0 & 61.1 & 38.6 \\
\hline \multicolumn{7}{|c|}{ Fortuna substation (dry years) } \\
\hline Dec 1-31 & 7.67 & 0.20 & 7.47 & 18.6 & 12.5 & 18.3 \\
\hline Jan & 12.88 & 0.05 & 12.83 & 32.0 & 21.4 & 16.0 \\
\hline Feb & 11.56 & 0.10 & 11.46 & 28.6 & 19.1 & 14.3 \\
\hline Mar $1-28$ & 9.22 & 0.10 & 9.12 & 22.8 & 15.2 & 11.4 \\
\hline Total & 41.33 & 0.45 & 40.88 & 102.0 & 68.1 & 51.0 \\
\hline \multicolumn{7}{|c|}{ Isabela substation (normal years) } \\
\hline Dec $]-31$ & 7.09 & 3.56 & 3.53 & 8.8 & 5.0 & 4.4 \\
\hline Jan & 11.84 & 3.54 & 8.30 & 20.8 & 13.8 & 10.4 \\
\hline Feb & 10.72 & 3.07 & 7.65 & 19.2 & 12.8 & 9.6 \\
\hline Mar $1-28$ & 8.64 & 2.87 & 5.77 & 14.4 & 9.6 & 7.2 \\
\hline Total & 38.29 & 13.04 & 25.25 & 63.2 & 42.1 & 31.6 \\
\hline \multicolumn{7}{|c|}{ Isabela substation (dry years) } \\
\hline Dec 1-31 & 7.09 & 2.51 & 4.58 & 11.4 & 7.6 & 5.7 \\
\hline Jan & 11.84 & 1.96 & 9.88 & 24.6 & 16.5 & 12.3 \\
\hline Feb & 10.72 & 1.39 & 9.33 & 23.4 & 15.6 & 11.7 \\
\hline Mar I-28 & 8.64 & 1.35 & 7.29 & 18.2 & 12.2 & 9.1 \\
\hline Total & 38.29 & 7.21 & 31.08 & 77.8 & 51.9 & 38.9 \\
\hline
\end{tabular}

experimental work was done at Isabela. During dry years, mean total effective rainfall was $4.5 \mathrm{~mm}$ at Fortuna and $72 \mathrm{~mm}$ at Isabela. Total NIR (mm) was 409 at Fortuna and 311 at Isabela. Monthly NIR (mm) was 75 for December, 128 for January, 115 for February, 91 for March at Fortuna; and 46 for December, 99 for January, 93 for February, 73 for March at Isabela. Seasonal GIR (mm) was 1020 for furrow, 681 for minisprinkler, 510 for drip irrigation at Fortuna; and 778 for furrow, 519 for minisprinkler and 389 for drip irrigation at Isabela. Average daily NIR (mm/day) was 3.5 at Fortuna and 2.6 at Isabela. No experimental work was conducted for dry years.

Table 7 shows NIR and GIR of tomato during the summer of 1987-86 at Fortuna and Isabela Agricultural Experiment Substations. During normal years, seasonal CU was $521 \mathrm{~mm}$ at Fortuna and 484 at Isabela. 
TABLE 7.-Estimation of gross imigation requirements of tomatoes at Fortuna and Isabela,

Summer tomatoes

\begin{tabular}{|c|c|c|c|c|c|c|}
\hline \multirow[b]{2}{*}{$\begin{array}{l}\text { MONTH } \\
1987-88\end{array}$} & \multicolumn{3}{|c|}{ Net irrigation requirement $(\mathrm{NIR}, \mathrm{cm})$} & \multicolumn{3}{|c|}{ Grass irrigation requirements (GIR,(cm) } \\
\hline & CU & $\mathrm{ER}$ & NIR & Furrow & $\begin{array}{c}\text { Mini } \\
\text { Sprinkler }\end{array}$ & Drip \\
\hline \multicolumn{7}{|c|}{ Fortuna substation (normal years) } \\
\hline April & 7.39 & 1.40 & 5.99 & 15.0 & 9.9 & 7.5 \\
\hline May & 16.08 & 4.47 & 11.61 & 29.0 & 19.4 & 14.5 \\
\hline June & 17.22 & 3.71 & 13.51 & 33.8 & 22.5 & 16.9 \\
\hline July $1-28$ & 11.40 & 2.62 & 8.78 & 22.0 & 14.6 & 11.0 \\
\hline Total & 52.09 & 12.20 & 39.89 & 99.8 & 66.5 & 49.9 \\
\hline \multicolumn{7}{|c|}{ Fortuna substation (dry years) } \\
\hline April & 7.39 & 0.28 & 7.11 & 17.8 & 11.9 & 8.9 \\
\hline May & 16.08 & 0.91 & 15.17 & 37.8 & 25.3 & 18.9 \\
\hline June & 17.22 & 0.76 & 16.46 & 41.2 & 27.4 & 20.6 \\
\hline July $1-28$ & 11.40 & 0.91 & 10.49 & 26.2 & 17.5 & 13.1 \\
\hline Total & 52.09 & 2.86 & 49.23 & 123.0 & 82.1 & 61.5 \\
\hline \multicolumn{7}{|c|}{ Isabela substation (normal years) } \\
\hline April & 6.86 & 3.40 & 3.46 & 8.6 & 5.8 & 4.3 \\
\hline May & 14.91 & 7.49 & 7.42 & 18.6 & 12.4 & 9.3 \\
\hline June & 15.98 & 6.99 & 8.99 & 22.4 & 15.0 & 11.2 \\
\hline July 1-28 & 10.69 & 4.37 & 6.32 & 15.8 & 10.5 & 7.9 \\
\hline Total & 48.44 & 22.25 & 26.19 & 65.4 & 43.7 & 32.7 \\
\hline \multicolumn{7}{|c|}{ Isabela substation (dry years) } \\
\hline April & 6.86 & 1.55 & 5.31 & 13.2 & 8.9 & 6.6 \\
\hline May & 14.91 & 3.40 & 11.51 & 28.8 & 19.2 & 14.4 \\
\hline June & 15.98 & 5.13 & 10.85 & 27.2 & 18.1 & 13.6 \\
\hline July $1-28$ & 10.69 & 2.62 & 8.07 & 20.2 & 13.5 & 10.1 \\
\hline Total & 48.44 & 12.73 & 35.71 & 89.4 & 59.5 & 44.7 \\
\hline
\end{tabular}

Mean total effective rainfall was $122 \mathrm{~mm}$ at Fortuna and $223 \mathrm{~mm}$ at Isabela. NIR was $399 \mathrm{~mm}$ at Fortuna and $262 \mathrm{~mm}$ at Isabela, which is equivalent to $3.3 \mathrm{~mm} /$ day at Fortuna and $2.2 \mathrm{~mm} /$ day at Isabela. Monthly NIR (mm) was 60 for April, 116 for May, 135 for June, 88 for July at Fortuna; and 35 for April, 74 for May, 90 for June, 63 for July at Isabela. Seasonal GIR (mm) was 998 for furrow, 665 for minisprinkler, 327 for drip irrigation at Fortuna; and 654 for furrow, 437 for minisprinkler, 327 for drip irrigation at Isabela. During dry years, seasonal CU was 521 $\mathrm{mm}$ at Fortuna and 484 at Isabela. Mean total effective rainfall was 29 $\mathrm{mm}$ at Fortuna and $127 \mathrm{~mm}$ at Isabela. Total NIR was $492 \mathrm{~mm}$ at Fortuna and $357 \mathrm{~mm}$ at Isabela, which is esquivalent to $4.1 \mathrm{~mm} /$ day at Fortuna and $3.0 \mathrm{~mm} /$ day at Isabela. Monthly NIR $(\mathrm{mm})$ was 71 for April, 152 for May; 165 for June, 105 for July at Fortuna; and 53 for April, 115 for May, 
109 for June, 81 for July at Isabela. Seasonal GIR (mm) was 1230 for furrow, 821 for minisprinkler, 615 for drip irrigation at Fortuna; and 894 for furrow, 595 for minisprinkler, and 447 for drip irrigation at Isabela. No field work was done for normal and dry years during summer.

In all cases, $\mathrm{CU}$ at Fortuna was 7.0 to $7.4 \%$ higher than $\mathrm{CU}$ at Isabela. Total NrR at Fortuna was 25-35\% higher than total NIR at Isabela. ${ }^{3}$

Table 8 indicates commercial tomato yield in the drip irrigated (T1), minisprinkler irrigated (T2), furrow irrigated (T3) and control plots (T4) during the winter at Fortuna agricultural experiment substation.

In the first harvest, $\mathrm{T} 1$ and $\mathrm{T} 2$ plots significantly increased $(\mathrm{P}=0.05)$ commercial yield of mature green and mature green + red tomatoes compared with Te and T4 plots. Weight of red tomatoes was not statistically different. In the second harvest, $\mathrm{T} 1$ plots significantly increased $(P=0.05)$ commercial yield of mature green and mature green + red tomatoes compared with those of $\mathrm{T} 2, \mathrm{~T} 3, \mathrm{~T} 4$ plots. $\mathrm{T} 4$ plots gave lowest yield of mature green and mature green + red tomatoes compared with all other plots at $\mathrm{P}=0.05$. Red tomato yield was highest in $\mathrm{T} 1$ and $\mathrm{T} 2$

TABLE 8..-Tomato response to irrigation methods and plastic mulch at Fortuna Agricultural Experiment Substation, Juana Diaz, P.R.

\begin{tabular}{clrrccc}
\hline & & \multicolumn{5}{c}{ Average commercial yield, tons/ha } \\
\cline { 3 - 7 } Inigation & Tomato & \multicolumn{5}{c}{ Harvesting date } \\
\cline { 3 - 7 } system & type & 18 Feb 88 & 1 Mar 88 & 15 Mar 88 & 18 Mar 88 & Total \\
\hline Drip & Green & 9.3 & 15.4 & 1.5 & 8.2 & 34.4 \\
(T1) & Red & 3.4 & 14.9 & 5.1 & 3.5 & 27.0 \\
& Total & 12.7 & 30.3 & 6.6 & 11.7 & 61.4 \\
Mini & & & & & & \\
Sprinkler & Green & 10.8 & 10.1 & 1.6 & 5.6 & 28.1 \\
(T2) & Red & 3.1 & 13.7 & 4.8 & 2.8 & 24.4 \\
& Total & 13.9 & 23.8 & 6.4 & 8.4 & 52.5 \\
Furrow & Green & 6.1 & 10.8 & 1.6 & 2.8 & 21.2 \\
(T3) & Red & 3.6 & 9.0 & 2.9 & 2.9 & 18.4 \\
& Total & 9.7 & 19.8 & 4.5 & 5.7 & 39.6 \\
Drip (1/2) & Green & 6.3 & 5.6 & 1.4 & 1.7 & 15.0 \\
(T4) & Red & 2.3 & 8.5 & 1.7 & 1.3 & 13.9 \\
& Total & 8.6 & 14.1 & 3.1 & 3.0 & 28.9 \\
\hline
\end{tabular}

${ }^{\mathrm{T}} \mathrm{T} 1=$ Drip irrigation (biwall drip line); $\mathrm{T} 2=$ Microsprinkler irrigation; $\mathrm{T} 3=$ Furrow irrigation (conventional); $\mathrm{T} 4=$ Control (drip inigated only for 45 days after transplanting).

"Goyal, M. R., 1988. Estimation of Monthly Water Consumption by Selected Crops in Semiarid and Humid Regions of Puerto Rico. Unpublished report by Agzicultural Experiment Station. Pages 413. 
plots $(\mathrm{P}=0.05)$ compared with $\mathrm{T} 3$ and $\mathrm{T} 4$ plots. In the third harvest, $\mathrm{T} 1$ and T2 plots gave higher yield of red and red + mature green tomatoes $(\mathrm{P}=0.05)$ than $\mathrm{T} 4$ plots. Differences were nonsignificant for mature green tomatoes. T1 plots gave the highest yield of mature green + red tomatoes $(\mathrm{P}=0.05)$ compared with $\mathrm{T} 3$ plots. In the fourth harvest, $\mathrm{T} 1$ plots yield highest $(\mathrm{P}=0.05)$ compared with $\mathrm{T} 2, \mathrm{~T} 3$, T4 plots in mature

TABLE 9.-Effects of irrigation methods on relationships among growth characteristics versis days after transplanting in tomatoes (Var. Duke)

\begin{tabular}{|c|c|c|c|c|}
\hline \multirow[b]{2}{*}{ Treatment } & \multicolumn{3}{|c|}{ Regression coefficients } & \multirow[b]{2}{*}{$\mathrm{R}^{1}$} \\
\hline & A & B & $\mathrm{C}$ & \\
\hline \multicolumn{5}{|c|}{ 1. Fresh plant weight, $g(X=44$ to 120$)$} \\
\hline $\mathrm{T} 1=$ Drip & 783.3 & 610.4 & 0.123 & 0.67 \\
\hline $\mathrm{T} 2=$ Microsprinkler & 818.3 & 1251.4 & 0.145 & 0.77 \\
\hline $\mathrm{T} 3=$ Furrow & 858.8 & 6365.5 & 0.168 & 0.84 \\
\hline $\mathrm{T} 4=$ Control & 745.8 & 1464.6 & 0.154 & 0.44 \\
\hline \multicolumn{5}{|c|}{ 2. Fresh fruit weight, $g(X=44$ to 120$)$} \\
\hline $\mathrm{T} 1$ & - & - & - & - \\
\hline $\mathrm{T} 2$ & 1337.9 & 208025610.2 & 0.322 & 0.74 \\
\hline T3 & 2169.2 & 1702410.2 & 0.251 & 0.65 \\
\hline T4 & 1116.8 & 1063991644.9 & 0.3412 & 0.39 \\
\hline \multicolumn{5}{|c|}{ 3. Fresh total weight, $\mathrm{g}(\mathrm{X}=44$ to 120$)$} \\
\hline $\mathrm{T} 1$ & 2368.9 & 658042.1 & 0.219 & 0.49 \\
\hline $\mathrm{T} 2$ & 2150.2 & 166892.7 & 0.212 & 0.85 \\
\hline T3 & 377.6 & 16.8 & - & 0.22 \\
\hline $\mathrm{T} 4$ & 1858.5 & 175494.6 & 0.2126 & 0.40 \\
\hline \multicolumn{5}{|c|}{ 4. Dry plant weight, $\mathrm{g}(\mathrm{X}=44$ to 120$)$} \\
\hline T1 & 110.5 & 65.1 & 0.068 & 0.85 \\
\hline $\mathrm{T} 2$ & 196.3 & 12.575 & 0.028 & 0.86 \\
\hline T3 & 162.1 & 16.4 & 0.0384 & 0.77 \\
\hline $\mathrm{T} 4$ & 111.7 & 243.8 & 0.0998 & 0.83 \\
\hline \multicolumn{5}{|c|}{ 5. Dry fruit weight ( $\mathrm{X}=44$ to 120 ) } \\
\hline $\mathrm{T} 1$ & 56.7 & 18031365.2 & 0.249 & 0.61 \\
\hline $\mathrm{T} 2$ & 47.6 & 79060.9 & 0.1799 & 0.87 \\
\hline T3 & 98.3 & 1.87 & - & 0.41 \\
\hline $\mathrm{T} 4$ & 51.7 & 21982750.3 & 0.2587 & 0.77 \\
\hline \multicolumn{5}{|c|}{ 6. Dry total weight, $g(X=44$ to 120$)$} \\
\hline $\mathrm{T} 1$ & 161.8 & 868.6 & 0.108 & 0.82 \\
\hline T2 & 204.1 & 24.7 & 0.0456 & 0.90 \\
\hline T3 & 153.7 & 1802.6 & 0.1321 & 0.83 \\
\hline $\mathrm{T} 4$ & 163.2 & 1337.1 & 0.1223 & 0.82 \\
\hline
\end{tabular}

' $Y=A /\left(1+B \times e^{-C \times X}\right)$,

where $\mathrm{Y}=$ growth parameter, $\mathrm{X}=$ days after transplanting; $\mathrm{A}, \mathrm{B}, \mathrm{C}=$ regression coefficients; $\mathrm{R}^{2}=$ coefficient of determination. All regression coefficients and coefficient of correlation were significant at $\mathrm{P}=0.05$. 
green and mature green + red tomatoes. Total yield was lower T4 plots $(\mathrm{P}=0.05)$ compared to $\mathrm{T} 2$ and $\mathrm{T} 3$ plots. Red tomato yield was lower in $\mathrm{T} 4$ plots $(\mathrm{P}=0.05)$ than in $\mathrm{T} 1$ plots.

Seasonal total commercial yield (tons/ha) was 34.4 - mature green, 27.0 - red, 61.4 - total in T1 plots; 28.1 - mature green, 24.4 - red, 52.5 - total in T2 plots; 21.2 green, 18.4 - red, 39.6 - total in T3 plots; 15.0 green, 13.9 - red and 28.9 - total in T4 plots, respectively. T1 plots gave higher yield of mature green, red, mature green + red tomatoes $(\mathrm{P}=0.05)$ than $\mathrm{T} 2, \mathrm{~T} 3, \mathrm{~T} 4$ plots. $\mathrm{T} 3$ and $\mathrm{T} 4$ plots yielded lower $(\mathrm{P}=0.05)$ in all cases than T2 plots. T4 plots yielded lower $(\mathrm{P}=0.05)$ in all cases than T3 plots. Drip, microsprinkler and furrow irrigation increased commercial tomato yield by $129 \%, 87 \%, 41 \%$ of mature green; $94 \%, 76 \%, 32 \%$ of red tomatoes; and $112 \%, 82 \%, 37 \%$ of mature green + red tomatoes, respectively.

Water use efficiency ( $t / \mathrm{ha}-\mathrm{cm})$ of tomato was 1.59 for drip, 0.86 for minisprinkler and 0.38 for furrow irrigation, respectively. This implies that drip irrigation was $54 \%$ more efficient than minisprinkle irrigation and $24 \%$ more efficient than furrow irrigation; and minisprinkler irrigation was $44 \%$ more efficient than furrow irrigation. Similar results have been reported by Navarro. ${ }^{4}$

Relationships among fresh plant-, fresh fruit-, fresh total-, dry plant-, dry fruit-, dry total weight versus days after transplanting were of sigmoidal type (table 9). All regression coefficients were significant at $\mathrm{P}=0.05$.

\section{LITERATURE CITED}

1. Climatography of the United States No. 20 of Puerto Rico and U.S. Virgin Islands. National Climatic Data Center - NOAA, United States Department of Commerce, Asheville, NC.

2. Drip/Trickle Irrigation in Action Vol I and II. Proceeding of the 1985 International Congress on Drip Irrigation by the American Society of Agricultural Engineers, St. Joseph-MI.

3. Finkel, H. J., 1983. Handbook of Irrigation Technology. CRC Press Inc. Vol. I and II.

4. Goyal, M. R., 1986. Seasonal water consumptive use of bell and Cubanelle peppers in the semiarid and humid regions of Puerto Rico. J. Agric. Univ. P.R., 79 (4): 609-14.

5. Hackbart, C. A., 1987. Consumptive Use Computer Model and SCS Users' Guide. USDA-SCS, Fort Worth-TX.

6. Jensen, M. E., 1980. Design and Operation of Farm Irrigation Systems. Monograph No. 3 by the American Society of Agricultural Engineers, St. Joseph-MI. Pages 189-225.

7. Practices for vegetables production. Agricultural Experiment Station, University of Puerto Rico - Mayagüez Campus, Rio Piedras. Publ. 102, March 1979.

8. Schawab, G. O., R. K. Frevert, T. W. Edminster and K. K. Barnes, 1981, Soil and Water Conservation Engineering. John Wiley \& Sons, New York. Pages 416-74.

'Navarro, A. A., 1988. Final report on irrigation water management for tropical crops. CBAG Grant No. 83-CRSR-2-2214, Univ. of US Virgin Islands, St. Thomas. August 31. 
9. Temperature data: Puerto Rico and U. S. Virgin Islands, updated 1984. National Climate Data Center, Asheville, NC.

10. USDA-SCS, 1970. Imigation Water Requirements. Engineering Division Technical Release No. 21. U.S. Gov't. Printing Office, Washington, D.C., Pages 1-88. 